\title{
The potential contribution of peri-urban wetlands to livelihood of local communities in Shinyanga Municipality, Tanzania
}

\author{
MOHAMED YUSUPH, P.K.T. MUNISHI \\ Department of Ecosystems and Conservation, College of Forestry, Wildlife and Tourism, Sokoine University of Agriculture. PO Box 3010, Chuo Kikuu, \\ Morogoro, Tanzania, "email: pmunishi2001@yahoo.com
}

Manuscript received: 8 October 2018. Revision accepted: 22 October 2018.

\begin{abstract}
Yusuph M, Munishi PKT. 2018. The potential contribution of peri-urban wetlands to the livelihood of local communities in Shinyanga Municipality, Tanzania. Bonorowo Wetlands 8: 75-83. The study took place in Shinyanga Municipality, Tanzania, to assess the potential contribution of peri-urban wetlands to the livelihood of nearby communities. The specific objectives were to examine the participation of the suburban wetland ecosystems to natural capital (food production/food security), evaluate the involvement of periurban wetlands ecosystem to financial capital (household income), and assess the advantages received by farmer groups/associations formed around the utilization of wetlands (social capital). Information was acquired through households and farmer's group/associations questionnaires, focus group discussions, and field observations. Data were analyzed using descriptive and inferential statistics by applying correlation and t-test. As many as $79.2 \%$ of the wetland nearby communities rely on the wetlands for food. The major food crops were paddy, fruits, vegetables, and sweet potatoes. The average production levels of cereals, vegetables, and fruits were prominently higher in wetlands compared to uplands. In the case of household income, wetland cultivation (paddy, vegetables, maize, and fruits) brought about a statistically higher household annual mean income of Tshs 2,335,852/year (US\$ 1,168) compared to Tshs 197,475/year (US\$ 99) produced by upland cultivation. The results further suggested that $70 \%$ of the farmer groups/associations established around wetland utilization accessed loans/credit to support agricultural production as an advantage from being members. Sustainable use of peri-urban wetlands in Shinyanga Municipality produces substantial livelihoods to adjacent communities. Conservation of such wetland ecosystems is indispensable for continued contribution to livelihoods while ensuring environmental protection. Further studies are necessary to unravel the nature of social capital associated with the utilization of wetland ecosystems.
\end{abstract}

Keywords: Livelihood, local communities, Shinyanga, urban wetlands

\section{INTRODUCTION}

Wetlands have been long considered a human life form resource for an extended period on earth, providing essential resources and offering shelter and food for humans and other forms of life (Ramsar Convention Bureau 2002). Wetlands cover around $0.6 \%$ of the earth's surface (Economics for the Environment Consultancy 2005), are among the world's most biologically productive environments, and are rich in biological species diversity (Munishi and Kilungu 2004). Wetlands contribute to the livelihoods of billions of people in the world and millions of African people through services and goods to a variety of users (IWMI 2010)

such as harvesting resources (forest, forage, wildlife, and fish), livestock grazing, and water supply (Dugan 1990). Africa wetlands cover about $4 \%$ of the total area of the landscape (Gichuki and Macharia 2006) in Eastern. Tanzania is a country gifted with unique wetland resources in which wetland ecosystems spanned about $10 \%$ of the country. These ecosystems range from large lake systems to river floodplains, deltaic mangrove formations, and associated catchments (Maltby 1986). Wetlands in Tanzania are a productive area in agricultural production, fish production, and source of pasture for livestock (Kashaigili 2006). Apart from agriculture and fishing, wetlands have vital importance in economic, social, cultural, and biological values. They generate income and employment for households and communities living near the wetlands.

The Government of Tanzania has demonstrated its concern towards the wise use of wetlands vi a local communities involved in managing and recognizing wetlands as primary natural resources, ecosystem services, and biological values by ratifying the Ramsar convention on wetlands in 2000 (MNRT 2003; 2004). Over the past ten years, there has been an increasing influx of people into wetland areas as a coping strategy, especially in regions where uplands are predominantly identified by low agricultural potential, dominated by low-quality soils, and unpredictable rainfall due to climate change (Turyahabwe et al. 2013).

The objectives of this research were to: (i) Examine the contribution of peri-urban wetland ecosystems to natural capital (land)-food production/food security. (ii) Evaluate the participation of local wetlands ecosystem to financial wealth-household income. (iii) Assess the benefits received by groups/associations of farmers (formal/ informal) formed around the utilization of wetlands (social capital) in the study area. 


\section{MATERIALS AND METHODS}

\section{Theoretical framework}

Overview of Sustainable Livelihood Approach (SLA)

The study was designed based on the conceptual framework of the Sustainable Livelihood Approach (SLA), which has been employed since the late 1990s as a development intervention and formed a central concept of the UK's Department for International Development's (DFID) strategy during the early years of the New Labour government in the UK (Morse et al. 2009). The call for an emphasis on sustainable livelihoods was set out in the 1997 White Paper on international development: refocus the international development efforts on eliminating poverty and encouraging economic growth, which benefits the poor society. We will do this through support for global sustainable development targets and policies that create sustainable livelihoods for poor people, promote human development and conserve the environment (DFID 1997). Chambers and Conway (1992) described that a livelihood comprises the capabilities, assets (stores, claims, resources, and access), and activities necessary for a means of living. A sustainable livelihood can survive and recover from shocks and stress, maintain or enhance its capabilities and assets, and give sustainable livelihood opportunities for the next generation.

Furthermore, livelihood contributes net benefits to other livelihoods at the local and global levels and in the short and long term. The theory takes much concern on equity of sustainable livelihood where people rely on those assets/capitals for their daily survival. Scoones (1998) mentioned five investments of sustainable livelihood, which were natural capital (natural resource stocks: soil, air, water, genetic resources) and environmental services (hydrological cycle, pollution sinks), human capital (skills, knowledge, labor includes good health and physical capability), economic or financial capital (cash, savings, credit/debit, and other economic assets), physical capital (infrastructure (roads, buildings), production equipment and technologies) and social capital (networks, social claims, social relations, affiliations, associations).

\section{The application of sustainable livelihood theory to peri- urban wetland ecosystem}

There is an interlink between peri-urban wetlands, which act as the primary asset with the sustainable livelihood of communities living adjacent to wetland landscapes. Such interrelationship associated with three capitals was helpful in the study's objectives whereby periurban wetland offered those of capitals that assure sustainable livelihood of local communities that utilized these small wetlands. The three capitals were natural capital (which provides water, fish, animal forage, land for food production, and environmental services), financial wealth (household income generated from the natural capital product (soil), and social capital (group membership and association membership capital from wetland soil products) (Figure 1).

Furthermore, there was a close interlink between three capitals by which natural capital in terms of land capital which used for food production and then ensuring food security to the livelihood of local communities who utilize peri-urban wetland. The surplus foods that are produced lead to the generation of household income, and that financial capital turns back also to the production of food. Financial capital facilitates the formation of social capital, which leads to the creation of groups and association memberships. On the other hand, social capital promotes back to the local communities' financial capital and natural capital (ensuring food security). In the end, those three capitals influenced the sustainable livelihood of local communities and the existence of peri-urban wetlands.

\section{Description of the study area}

Geographical location

Shinyanga Municipality is bordered to the north by the Mwanza Region, east by the Kishapu District, south by the Shinyanga Rural District, and west by the Kahama District. It is one of the districts of the Shinyanga Region of Tanzania; the District lies between latitude $3^{\circ} 20^{\prime}$ and $3^{\circ} 45^{\prime}$ South of the Equator and longitude $33^{\circ} 20^{\prime}$ and $35^{\circ} 35^{\prime}$ East of the Greenwich Meridian (URT 2013). The study was done in four villages of Mwalugoye, Old Shinyanga, Chamaguha, and Mwagala (Figure 2)

The district covers a total area of about 548 square kilometers which is about $1.1 \%$ of the whole area square of the Shinyanga region (URT 2007). Administrative the District has about three divisions and 17wards, 19 Villages, 25 Mitaa, and 95 Hamlets. The topographical region is flat lowland with small hills in the North West and West. The district has a gentle slope in the North, South, and the East. The Municipality area is separated into two main regions, the urban properly covering 25 square kilometers and the rural area with 523 square kilometers. The rural area of the district covers 95.4 percent of the total land area while the urban proper covers the remaining (Shinyanga Municipal Profile 2014).

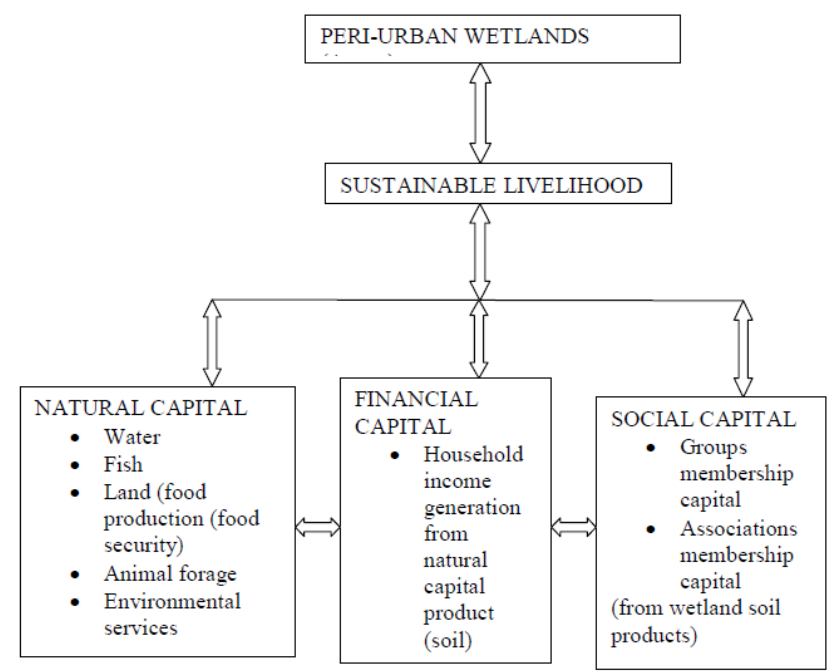

Figure 1. A conceptual framework for sustainable livelihood analysis of peri-urban wetland assets/capital. Source: Author construct with many contributions from The UK's DFID Sustainable Livelihoods framework (DFID 1997) 

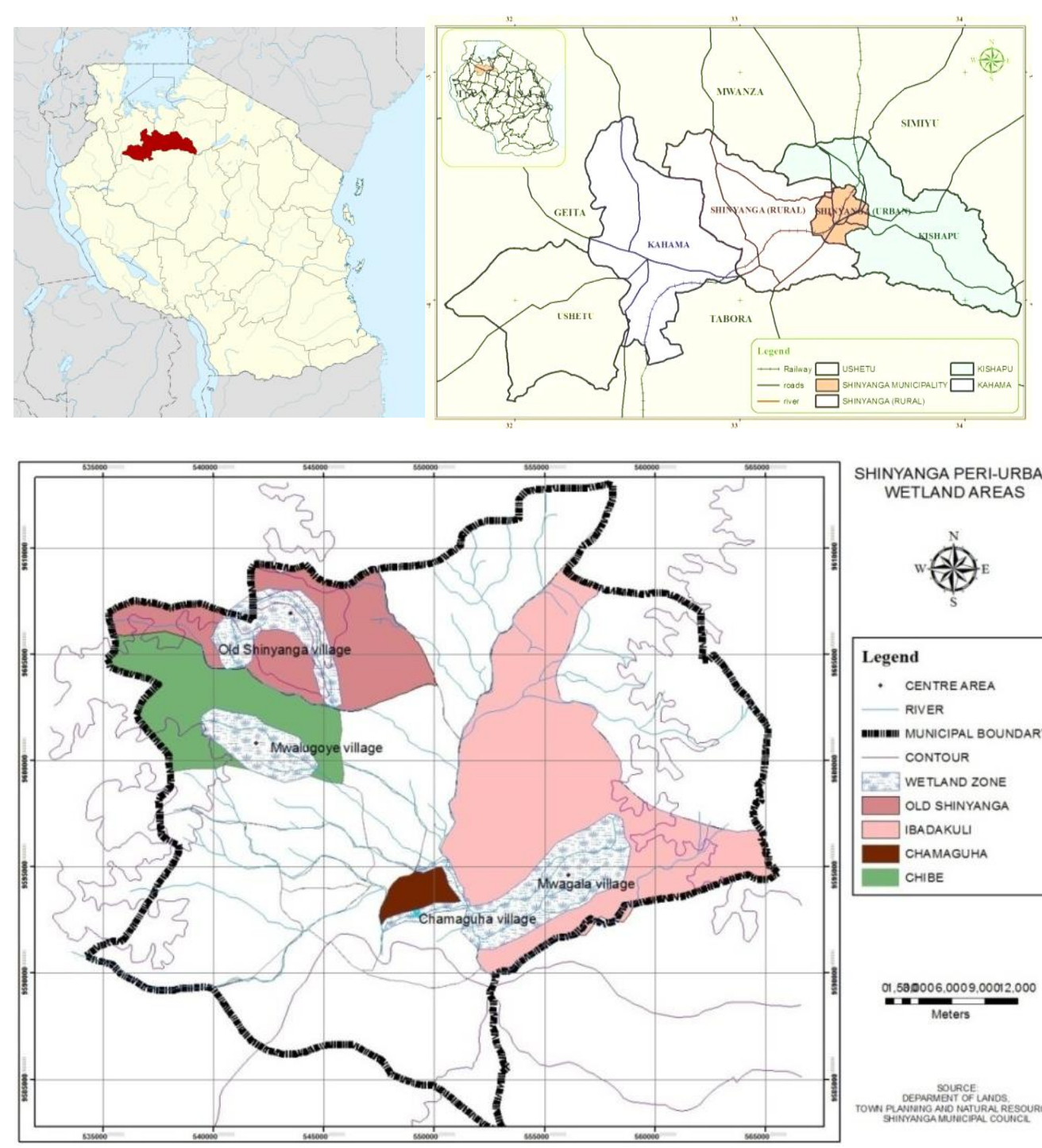

SHINYANGA PERI-URBAN WETLAND AREAS

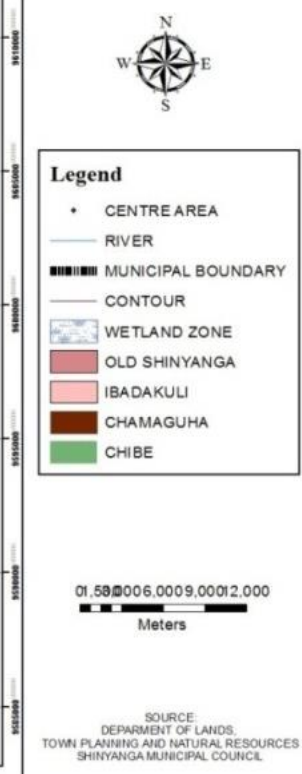

Figure 2. A map of Shinyanga Municipal Council displaying three study villages; Mwalugoye, Old Shinyanga, Chamaguha and Mwagala

\section{Population}

The council population is 161,391 people, as provided by the 2012 Population Census and Housing report, which consists of 78,655 males and 82,736 females with an average household of 4.8 persons (URT 2013). In 2013, the projected population was estimated to be 165,749 based on an inter-census annual growth rate of $2.7 \%$.

\section{Climate}

In general, the municipality experiences a tropical weather characterized by two seasons: the rainy season that starts in October and ends in December of the same year, and then the dry season. The seasons, again, it launches in March the following, the year coming to an end in April or early May. The dry season begins in May to mid-October and January to February (Shinyanga Municipal Profile 2014). Average rainfall per year ranges between 600$1000 \mathrm{~mm}$ (URT 2007). The maximum average temperature ranges between $20^{\circ} \mathrm{C}$ to $31^{\circ} \mathrm{C}$, and minimum temperatures averages between $18^{\circ} \mathrm{C}$ to $24^{\circ} \mathrm{C}$.

\section{Vegetation and soil}

Shinyanga was extensively forested with Acacia, miombo species, and forest products and services in the early 1920s (Malcolm 1953). But nowadays, the vegetation is mainly of acacias bush with panicum and Chlorisgayana as the significant grass species. Natural legumes like tropical kudzu are sparsely distributed in the grazing land. The soil is clay, but in some areas, clay-loam soils are observed (Shinyanga Municipal Profile 2014).

\section{Social, economic activities}

The primary activities in the district are Agriculture, industries, livestock keeping, mining, and business. The food crops grown are paddy, maize, sorghum, sweet potatoes, cassava, millet, and to some extent, cotton is also cultivated as a cash crop in the study area (NBS 2002). The livestock are mainly cattle, sheep, goats, donkeys, pigs, and poultry (URT 2007). The primary ethnic group of the study area is the Wasukuma. 


\section{Sampling procedures}

Purposive sampling was applied to select wards that have wetlands because not all wards in Shinyanga Municipal have wetlands. The chosen wards were sampled using simple random sampling to get four wards. Then, purposive sampling was applied again within four wards to obtain wetlands villages because not all communities have wetlands. The villages with wetlands were sampled using simple random sampling to get four villages where the study was conducted. The four sampled communities were selected purposely based on accessibility and proximity to the wetland.

The selected villages were Mwalugoye, Old Shinyanga, Mwagala, Chamaguha. Households were taken as sampling units, whereby 30 families were chosen randomly in each town to get a total sample size of 120 . The 30 houses were taken as sampling units in every four communities because the nature of the study required doing so. After all, the study focused on families who own land in wetlands and upland and village registers. There was no data for the number of families who own property in wetlands and uplands. Therefore, 30 households were selected randomly in each village to get a total sample size of 120 , which is considered an adequate number to fulfill the requirements of efficiency, reliability, and representativeness (Kothari 2010). Purposive sampling was also conducted to get farmer groups/associations which utilize wetland farmland from four selected villages. There were about 36 groups/associations involved in wetland agriculture in four communities, where there were nine groups/associations for each town. From 9 groups/associations, five groups/associations were randomly sampled to represent the whole sample size in each city. Therefore, to get a sample size of 20 groups/associations for four communities, Mwalugoye, Old Shinyanga Chamaguha, and Mwagala.

\section{Data collection}

Primary and secondary data were collected for this study. The secondary data sources were books, journals, records from Web resources, Sokoine National Agriculture Library (SNAL), and Regional and Municipal Agricultural, Planning, and Natural resources offices. The primary data were taken to fill the gap of whatever was not found from secondary data. The preliminary data were obtained through questionnaires, field observations, focus group discussion (FGD) using checklists of probe questions, and critical informant interviews at the district level. Collecting data involved many steps: reconnaissance survey, questionnaire survey, focus group discussion, key informant interviews, and participant field observation.

\section{Reconnaissance survey}

This was done to get the whole picture of the research location. This stage involved visiting wetland farms, choosing sample units, and pre-testing questionnaires. Five households were randomly selected and interviewed to pretest the poll to check the reliability and validity of the questions. This was also done for farmer groups/ associations where one group/association was randomly selected and interviewed from each identified village.

\section{Questionnaire survey}

Questionnaire forms were distributed for each household sampling unit and farmer groups/associations. Interviews were done face-to-face where the researcher had to reach the respondents at their place and sometimes to their farmland when the head of the household was on the farm.

The questionnaire was made to acquire information from leaders of families regarding the contribution of wetland products to the household's income and food security. The data included, among others, household social economic characteristics, amount of food produced in wetland crops and upland crops, the total size of the wetland farm, and cash earned from wetland agricultural products and upland agrarian products. Unit price per bag/Tenga was estimated using (Tshs) and converted into USD. Types and amounts of a variety of foods produced or harvested were measured using units familiar to local people such as "debe," "kopo," "tengas," etc., and those units were converted into standard units (kgs). Interviews were face-to-face with the groups/association members. Each group/association organized and agreed on the right place to meet. The questionnaire was made to acquire information from each group regarding the benefits received by members who utilize the wetlands through groups/associations.

\section{Key informants}

Interviews with key informants knowledgeable on wetland and upland agricultural activity were performed using a checklist. These included the District Agriculture Officer, District Natural Resources Officer, and District Planning Officer. The information required included a standard period of food shortage and food availability, general social and economic characteristics of the wellbeing of households in the district regarding the source of income, occupation, food, management of wetland by government, and accessibility of the wetlands to adjacent communities.

\section{Participant field observation}

Field observations by the researcher are significant because they aid the researcher in contrasting the information given by respondents and the actual situation in the field (Kajembe and Wiersum 1998). The data collected included the general condition of crop farming, types of food grown in the wetlands and uplands, and the size of wetland farmland.

\section{Focus group discussion}

Focus group discussion (FGD) was applied because it provides precise information from different knowledgeable persons. The method involved the use of a checklist to facilitate discussions. FGD involved Ward/ Village Executive Officers, Ward/Village Extension Officers, Village Committees, Environment Committee leaders, men and women, elders, middle-aged, youth, and famous people in 
the village. Ten participants for group discussion came from each community. The information discussed included the sort of food crops grown in wetlands, parameters affecting wetland crop production, crop calendar for plants cultivated in wetlands, and types of food crops grown in the swamps. Others were the standard period of food shortage, coping strategies for food shortage, and strategies to sustain wetlands.

\section{Data analysis}

Content analysis

The PRA data, such as participant observation, were analyzed by content analysis. The recorded dialogues were broken down and put into a meaningful argument then conclusions were drawn. Data from FGD and key informants were analyzed with the assistance of people in the field. The FGD and critical informants' data were presented in the elusive form. The data were used to add information to the questionnaire tool.

\section{Questionnaire data}

Statistical Package for Social Sciences (SPSS) software was applied for descriptive statistics and Excel for windows software. The descriptive statistical analysis included arithmetic mean, standard deviation, frequencies, and percentages. The t-test was used to compare the mean value of household cash income and amounts of foods acquired from wetland fields and upland fields. This study tested the correlation of group/association formed factors (in terms of registration and average income per member) against the benefits of wetland utilization (in terms of Government support and food security).

\section{RESULTS AND DISCUSSION}

\section{Socio-economic characteristics of sampled household respondents}

The main characteristics considered were age, marital status, gender, main economic activities, education level, household size, and residence duration (Table 1).

\section{Gender and age}

The results show that about $72.5 \%$ of respondents were males, and $27.5 \%$ were females. This means that men are the majority as household heads because the study was considered heads of households. It has been argued that with African society's traditions, males will appear as household heads (Bwana 1996; Magembe 2007). Gender relations are a significant factor in respect to household activities with a connotation on household production and income. Male and females contribute to the family income and ensure food security through wetland agricultural activities.

The proportion of respondents aged group 39-60 was $54.2 \%$, followed by $18-38(29.2 \%)$. This indicated that most people in the surveyed area were energetic enough to contribute to agriculture production in wetlands farming. The age distribution of a community determines to a large extent the potential productive force in a city. Household members are considered economically productive at the age of 16 to 64 years (Mtenga 1999). Also, the respondents aged over 60 agriculture probably because they are deemed unfit in offering workforce according to Ishengoma (1998).

\section{Marital status}

Approximately $75 \%$ of the respondents were married couples, $4.2 \%$ were single, $6.6 \%$ were separated, $10.8 \%$ were widowed, and $3.3 \%$ were divorced. These results concur well with the Tanzania Bureau of statistics 2014 that more than $50 \%$ of Tanzania Mainland adults are married, given that married couples have more mouths to feed. The use of wetlands to produce food and income to feed the family will likely increase with the increasing number of married couples. Since most of the respondents are married, the utilization intensity of the wetlands is expected to be high.

Table 1. Socio-economic characteristics of the respondents in study villages

\begin{tabular}{|c|c|c|c|c|c|}
\hline \multirow[b]{2}{*}{ Category } & \multicolumn{4}{|c|}{$\%$ of respondents $(\mathrm{n}=30)$} & \multirow[b]{2}{*}{$\begin{array}{c}\text { All } \\
(\mathrm{N}=120\end{array}$} \\
\hline & 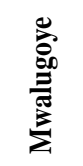 & 응 总 & 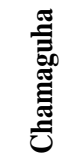 & 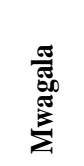 & \\
\hline \multicolumn{6}{|l|}{ Gender } \\
\hline Male & 83.3 & 66.7 & 76.7 & 63.3 & 72.5 \\
\hline Female & 16.7 & 33.3 & 23.3 & 36.7 & 27.5 \\
\hline \multicolumn{6}{|l|}{ Age class } \\
\hline $18-38$ & 33.3 & 36.7 & 23.3 & 23.3 & 29.2 \\
\hline $39-60$ & 43.3 & 50.0 & 60.0 & 63.3 & 54.2 \\
\hline Above 60 & 23.3 & 13.3 & 16.7 & 13.3 & 16.7 \\
\hline \multicolumn{6}{|l|}{ Marital status } \\
\hline Single & 10.0 & 3.3 & 0.0 & 3.3 & 4.2 \\
\hline Married & 63.3 & 80.0 & 83.3 & 73.3 & 75.0 \\
\hline Separated & 6.7 & 6.7 & 6.7 & 6.7 & 6.7 \\
\hline Widowed & 16.7 & 6.7 & 10.0 & 10.0 & 10.8 \\
\hline Divorced & 3.3 & 3.3 & 0.0 & 6.7 & 3.3 \\
\hline \multicolumn{6}{|l|}{ Education level } \\
\hline Non-formal education & 20.0 & 23.3 & 23.3 & 20.0 & 21.7 \\
\hline Adult education only & 0.0 & 0.0 & 3.3 & 10.0 & 3.3 \\
\hline Primary education & 63.3 & 56.7 & 50.0 & 60.0 & 57.5 \\
\hline Secondary education & 16.7 & 16.7 & 13.3 & 10.0 & 14.2 \\
\hline Tertiary education & 0.0 & 3.3 & 10.0 & 0.0 & 3.3 \\
\hline \multicolumn{6}{|l|}{ Main economic activities } \\
\hline Trading and small business & 0.0 & 13.3 & 13.3 & 13.3 & 10.0 \\
\hline Formal employment & 3.3 & 10.0 & 6.7 & 3.3 & 5.8 \\
\hline Crop farming only & 56.7 & 33.3 & 36.7 & 30.0 & 39.2 \\
\hline $\begin{array}{l}\text { Crop farming \& livestock } \\
\text { keeping }\end{array}$ & 40.0 & 43.3 & 43.3 & 53.3 & 45.0 \\
\hline \multicolumn{6}{|l|}{ Household size } \\
\hline $1-3$ persons & 20.0 & 33.3 & 23.3 & 10.0 & 26.7 \\
\hline 4-6 persons & 36.7 & 43.3 & 63.3 & 67.7 & 49.2 \\
\hline 7-9 persons & 36.7 & 16.7 & 10.2 & 16.7 & 21.7 \\
\hline $10-12$ person & 6.7 & 6.7 & 3.3 & 6.7 & 2.5 \\
\hline \multicolumn{6}{|l|}{ Residence duration } \\
\hline $1-20$ years & 10.0 & 6.7 & 20.0 & 6.7 & 10.8 \\
\hline $21-40$ years & 46.7 & 36.7 & 23.3 & 26.7 & 33.3 \\
\hline $41-60$ years & 30.0 & 43.3 & 43.3 & 53.3 & 42.5 \\
\hline Above 61 & 13.3 & 13.3 & 13.3 & 13.3 & 13.3 \\
\hline
\end{tabular}




\section{Education level}

The education level of the respondents is shown in Table 1. most of the respondents attained primary education $(57.5 \%)$. The proportion of those with secondary school (14.2\%), tertiary education (3.3\%), and adult education $(3.3 \%)$ was relatively low. Besides, $21.7 \%$ of the respondents had no formal training. A school directly influences people's knowledge and participation in natural resources management. It promotes the utilization of natural resources suggests (1999) indicates that an increase in education level increases awareness, thereby creating positive attitudes values and thus motivating people to manage natural resources sustainably.

Maro (1995) argued that education plays a significant role in the socio-economic development of any society. It fosters human creativity and innovations in natural vegetations management into traditional systems of land use management. Kajembe and Luoga (1996) described no development without education. The increase in the level of education also raised respondents' options to meet their livelihoods. In this study, the majority of the population had a primary education which may entail unsustainable utilization of the wetlands due to limited conservation knowledge. Most of the respondents who completed primary school were involved in wetland farming compared to those who attained a relatively higher education level.

\section{Main economic activities}

The primary economic activities of the respondents include crop farming, livestock keeping, and small business (Table 1). The majority of respondents practiced a combination of crop farming and livestock keeping (45.0\%), crop farming only (39.2\%). Few respondents were involved in small businesses $(10.0 \%)$ and formal employment $(5.8 \%)$. Wetland farming and livestock were the significant activity by the majority of the population resulting in the intensive utilization of wetlands for farming and livestock grazing.

Traditionally Wasukuma is agriculturist and livestock keeper in Tanzania. The major plants grown in the study area were paddy, maize, cassava, sweet potatoes, vegetables (spinach, amaranthus, mchicha, cabbage), and fruits (tomatoes and watermelon). Livestock includes goats and cattle. Interviews and participant observations demonstrated that crop production was complemented by other small businesses, including the selling of agricultural products such as rice, tomatoes, maize, sweet potatoes, and vegetables.

\section{Household size}

The majority (49.2\%) of households had about 4-6 persons per household, followed by $1-3$ persons $(26.7 \%)$, 7-9 persons (21.7), and 10-12 (2.5\%) (Table 1). Family size is an essential feature for determining the extent to which labor power is necessary for food production and income. It reflects the household's access to sufficient food, income, and other basic needs. Yanda et al. (2005) reported that available labor influences wetland productivity. This implies that households with large family sizes are likely to have more labor force enough to utilize wetland resources than small family sizes effectively. However, Lorri and Kavishe (1990) argued that big family size contributed to food insecurity in Tanzania.

\section{Residence duration}

The majority (42.5\%) of the population had 41-60 years of residence in the area, followed by $21-40$ years $(33.3 \%)$. This indicated that indigenous people possessed most of the wetland farmlands, hence contributing to full utilization of wetland resources for an extended period.

\section{Location of farmland and land holdings in wetland and upland farmland}

About $56.7 \%$ of the population possessed farmlands in wetlands and uplands, thereby undertaking wetland and upland cultivation, while a good proportion (36.7\%) own farms in the swamp. Upland agriculture was done by a relatively low number of the population (Table 2) showing that wetland cultivation is undertaken by a substantially large number of the people. The high percentage of wetlands utilization was because most wetlands are fertile and have sufficient access to water throughout the year which convinces more yields. The results are in line with those of Majule (2007) who reported that majority of farmers would have both wetland and upland farmland because both wetland and upland complement each other as a crucial source of livelihood.

Table 2. Location of farmland and land holdings in wetland and upland farmland in study villages

\section{\% of Respondents $(n=30)$}

\begin{tabular}{|c|c|c|c|c|c|}
\hline Item & 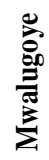 & 음 冚 & 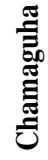 & 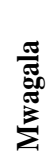 & $\underset{(\mathbf{N}=120)}{\text { All }}$ \\
\hline
\end{tabular}

\section{Location of farmland}

$\begin{array}{lccccc}\text { Wetland } & 20.0 & 26.7 & 36.7 & 36.7 & 36.7 \\ \text { Upland } & 10.0 & 6.7 & 3.3 & 6.7 & 6.7 \\ \text { Both } & 70.0 & 66.7 & 60.0 & 56.7 & 56.7\end{array}$

Size of land (wetland)

$\begin{array}{lccccc}\text { 0.00 } & \mathbf{1 0 . 0} & \mathbf{6 . 7} & \mathbf{3 . 3} & \mathbf{6 . 7} & \mathbf{6 . 7} \\ \text { Below 0.5ha } & 6.7 & 3.3 & 10.0 & 6.7 & 6.7 \\ \text { 0.5-1.5ha } & 26.7 & 26.7 & 36.7 & 46.7 & 34.2 \\ \text { 1.6-2.5ha } & 20.0 & 40.0 & 33.3 & 33.3 & 31.7 \\ \text { 2.6-3.5ha } & 16.7 & 16.7 & 13.3 & 6.7 & 13.4 \\ \text { Above 3.5ha } & 20.0 & 6.7 & 3.3 & 0.0 & 7.5\end{array}$

\begin{tabular}{lccccc} 
Size of land (upland) & & & & & \\
0.00 & $\mathbf{2 0 . 0}$ & $\mathbf{2 6 . 7}$ & $\mathbf{3 3 . 3}$ & $\mathbf{3 3 . 3}$ & $\mathbf{2 8 . 3}$ \\
Below 0.5ha & 3.3 & 10.0 & 3.3 & 3.3 & 5.0 \\
0.5-1.5ha & 6.7 & 6.7 & 6.7 & 3.3 & 5.8 \\
1.6-2.5ha & 10.0 & 10.0 & 20.0 & 6.7 & 11.7 \\
2.6-3.5ha & 13.3 & 6.7 & 20.0 & 13.3 & 13.3 \\
Above 3.5ha & 46.7 & 40.0 & 16.7 & 40.0 & 35.8 \\
\hline
\end{tabular}

Note: 0.00 mean respondents who did not own farms in either wetlands or uplands 
Moreover, the majority of farmers $(65.9 \%)$ owned plots of between $0.5-2.5 \mathrm{ha}$ in wetland areas while in upland regions majority of farmers $(35.8 \%)$ have a plot of above 3.5 ha and also the majority $(28.3 \%)$ of respondents who were surveyed did not have plots in upland areas. Most of the respondents have small portions of farms in wetland areas because of the massive demand of these farmlands connected with their productivity. Sarris et al. (2006) also reported that smallholder farming in Tanzania is characterized by the average size of cultivated land of between 1ha and 3ha. During an interview with key informants and FGD, not all members of communities studied have access to wetland farms due to a shortage of farmland in wetlands.

\section{Contributions of Peri-urban Wetland Ecosystems to} Natural Capital (Land)-Food Production/Food Security Types and amount of food crops produced in peri-urban wetlands

Most of the communities who live adjacent to local wetland resources rely on the wetlands in obtaining their food for sustaining their livelihoods (Table 3). Food crops grown in sub-urban wetland farmlands in Shinyanga Municipality are mainly cereal crops (rice and maize), vegetables (spinach, mchicha, cabbage, eggplant, green pepper, Chinese cabbage), root crops (sweet potatoes and cassava), and fruits crops (tomatoes, watermelon, and sugarcane). Further analysis demonstrated that production of cereals was the highest followed by fruits and root crops. Table 4 shows that vegetable ranked the lowest in production.

T-test showed that average production levels of cereals, vegetables, and fruits were significantly higher in wetlands $(\mathrm{p}<0.001)$. The production of root crops, on the contrary, was not significantly different between the two sites. These findings are similar to previous observations which indicated that $80 \%$ of cereals were produced in wetland areas in Illubabor Ethiopia (Abort and Hailu 2000).

Additionally, during focus group discussions it was stated that wetland crop productivity was affected by various constraints such as lack of appropriate water management especially during dry seasons in each year causing water scarcity among wetland resource users.

People in the study area depended mostly on rice and maize as their staple foods. Rice varieties grown in the area included hybrids such as"Katani," "Omana," "Kahogo," and "Super." Sugar cane is also produced in Mwalugoye and Old Shinyanga villages as one of the commercial crops contributing significantly to household income. Vegetables and fruits are grown particularly during dry seasons after harvesting paddy, and in that period people rely on river Mhumbu as the nearest water source for Chamaguha and Mwagala villages.

\section{The contribution of wetland cultivation to household food availability.}

The usage of wetlands ensures food supply throughout the year for the majority of the adjacent communities. About $75 \%$ of the neighboring people produce food from the wetland fields the whole year. A small proportion produces food for at least three up to six months a year (Table 5). Vegetables, fruits, and sweet potatoes are produced throughout the year whereas most cereals (paddy and maize) are produced for only six months, and root crops are for three months. Sweet potatoes are the primary crop grown in large quantities in both wetland and upland farm fields.

During FGD it was reported that the months where households experience food shortage were from OctoberFebruary and during this times most of the houses depended on root crops particularly sweet potatoes which were preserved after the harvesting period (michembe) for reducing household food shortage.

\section{The contribution of Peri-urban wetlands to financial capital-household income}

The average annual household income contributed by agriculture production in wetlands amounted to Tshs of 1 114583.33 (US\$ 557) from paddy, Tshs 849500 (US\$ 425) from fruits and Tshs 214583.33 (US\$ 107) from vegetables and Tshs 157185 (US\$ 79) from maize. It makes a total mean value annual income of Tshs 2335852 (US\$ 1168) (Table 6). It was reported during FGD that paddy production gives farmers high income because its output is as high as compared to other crops and the market for paddy is available.

Table 3. Farmland depended for obtaining food for community livelihood

\begin{tabular}{lcc}
\hline \multicolumn{1}{c}{ Item } & Frequency & Percent \\
\hline Wetland & 95 & 79.2 \\
Both wetland and upland & 25 & 20.8 \\
Total & $\mathbf{1 2 0}$ & $\mathbf{1 0 0 . 0}$ \\
\hline
\end{tabular}

Table 4. Comparison of the average household amount of food produced from wetland and upland farmland field in study villages

\begin{tabular}{|c|c|c|c|c|}
\hline \multirow{2}{*}{$\begin{array}{c}\text { Yield production } \\
\text { in kg } \\
\text { Type of crop } \\
\end{array}$} & \multicolumn{4}{|c|}{ t-test } \\
\hline & Wetland & Upland & t-value & Sig. (2tailed) \\
\hline \multirow[t]{2}{*}{ Cereals } & Mean & 2542.92 & 392.83 & $0.000 * * *$ \\
\hline & SD & 103.97 & 41.09 & \\
\hline \multirow[t]{2}{*}{ Fruits } & Mean & 591.00 & 5.75 & $0.000 * * *$ \\
\hline & SD & 59.59 & 2.15 & \\
\hline \multirow[t]{2}{*}{ Root crop } & Mean & 308.17 & 311.50 & $0.092 \mathrm{Ns}$ \\
\hline & SD & 39.75 & 40.79 & \\
\hline Vegetable & Mean & 203.21 & 2.79 & $0.000 * * *$ \\
\hline SD & 25.33 & 0.70 & & \\
\hline
\end{tabular}

Table 5. Periods of production of different crops in a year in periurban wetlands in the study area

\begin{tabular}{lcc}
\hline \multicolumn{1}{c}{ Time length } & Frequency & Percent \\
\hline Three months & 6 & 5.0 \\
Six months & 24 & 20.0 \\
All around the year & 90 & 75.0 \\
Total & 120 & 100.0 \\
\hline
\end{tabular}


T-test analysis (Table 6) shows a significantly higher $(\mathrm{P} \leq 0.001)$ household income from wetland cultivation than upland cultivation for paddy, vegetables and fruits production. The reasons behind such differences might be attributed to the fact that most respondents invest more in wetlands because of the availability of more fertile soil and adequate water in wetland areas. This proposition is in resemblance to the study carried out in Sri Lanka which indicated that farmers chose to use wetlands due to fertile agricultural land and the ability to control the water (moisture) (Nagabhatla et al. 2006).

Another study in Singida described similar reason that farmers utilize wetlands for rice cultivation due to the high yields and high soil fertility, which in turn contributed to household cash income (Yanda et al. 2005). Moreover, there was no significant difference for cash income generated from maize productions between wetlands and upland farmlands since the cash income generated from maize crop is relatively higher in both sites.

\section{Social capital benefits accruing from utilization of wetlands}

There are substantial social capital benefits that occur from the utilization of wetlands including associations (formal/informal) formed around the usage of wetlands. Thirty-six farmer groups/associations have been developed in the four villages of Mwalugoye, Old Shinyanga, Chamaguha and Mwagala. Figure 3 shows about $75 \%$ of 20 sampled groups/associations generate income from wetlands farming, credits/microfinance (15\%), salary/ wages $(5 \%)$ and the rest $5 \%$ from investment/business. Wetland production, therefore, makes a significant and substantial income earner farmer's group/association members. According to group members, paddy which was produced from wetlands generates the highest income compared to the other crops.

\section{Benefits received by farmer groups/associations}

Figure 4 shows the benefits that farmer groups received from being members of particular associations. Such benefits contain access to loans/credits (70\%), access to agriculture inputs (10\%) and access to agricultural extension services (5\%). This implies the formation of farmers in groups/associations is related to benefits that would not be available without the associations. Loans received from within associations (Table 7) support agricultural activities through hiring farmland, buying farming inputs and paying farm laborer.

\section{Relationship between registration of groups/ associations and government supports}

In this benefit, a correlation test was used to measure relationship between groups/association registration and government supports. Non-parametric bivariate correlation analysis showed a significant positive correlation between groups/associations registration and government support $(\mathrm{r}$ $=0.681, \mathrm{P}=0.01)$ which means that groups/associations which were registered by government received more government supports in various aspects such as agricultural inputs (power tillers, water pump, pesticides, seeds and incentive fertilizers), adequate agricultural extension services and small to medium size loans. This is because farmers who organized themselves into registered groups use more effectively the benefits from the municipal compared the unregistered groups.

Table 6. Comparisons of mean total cash income earned from wetland and upland agricultural products in study villages

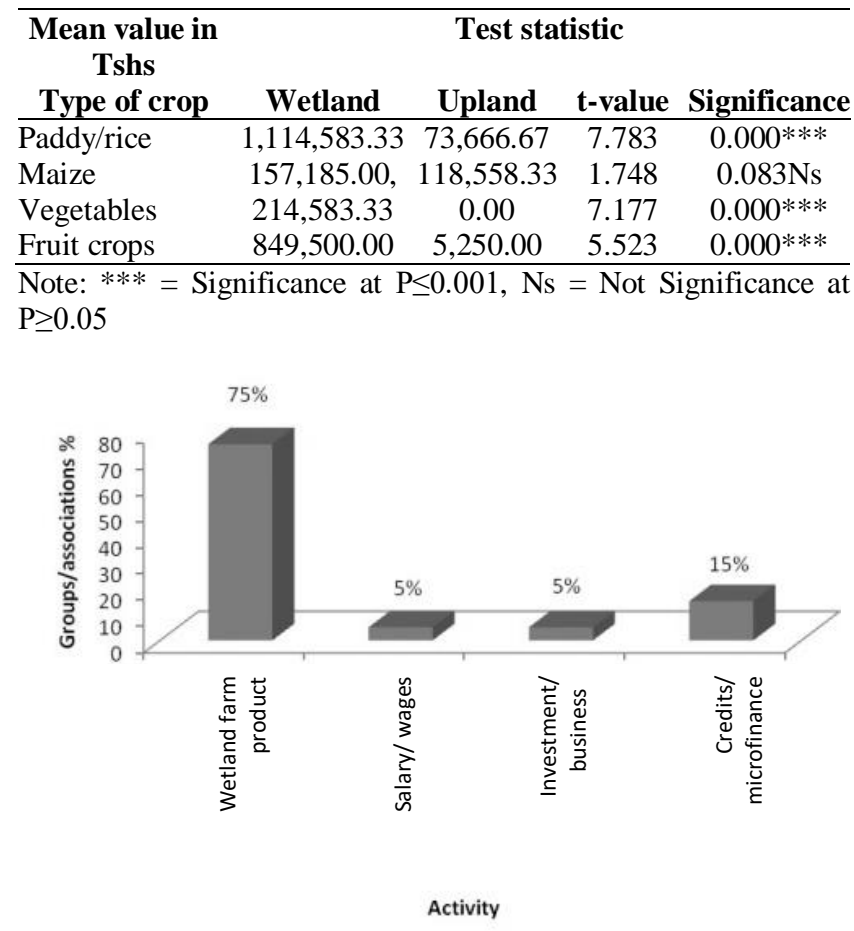

Figure 3. Primary source of income for group/association members in study villages

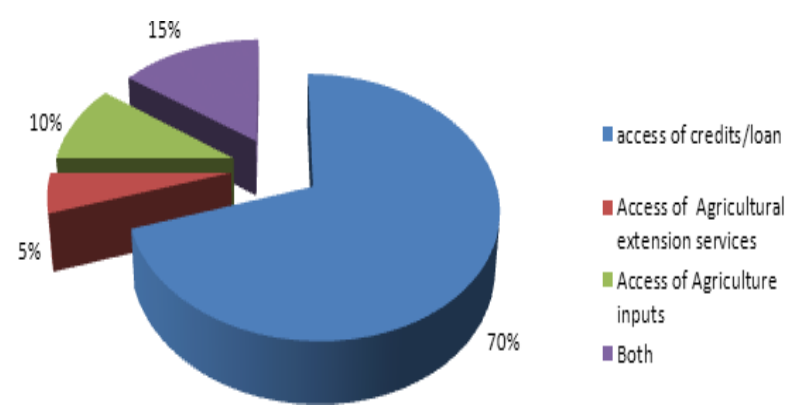

Figure 4. Benefits received by wetland farmer's

Table 7. Sources of loans for farmers group/associations in study villages

\begin{tabular}{lcc}
\hline \multicolumn{1}{c}{ Item } & Frequency & Percent \\
\hline Within the group/association & 14 & 70.0 \\
Banks & 1 & 5.0 \\
Small loan institutions & 3 & 15.0 \\
Both & 2 & 10.0 \\
Total & 20 & 100.0 \\
\hline
\end{tabular}




\section{Relationships between average income per group/ association members and food security in their households}

There was significant positive correlation between average income per group member and food security $(\mathrm{r}=$ $0.862, \mathrm{P}=0.01)$. This means that members of groups who had higher average income were more food secure throughout the year. This implies that higher income from wetland agricultural crops contributes to household food security among group members. Most farmers in groups depend on rice crop production as their main source of income and food. The income farmer's groups/association generate is used to buy food hence ensuring food security in their household.

\section{Conclusion}

Peri-urban wetlands contribute substantially to household food security through production of various agricultural crops which grow well in wetland areas. Periurban wetlands contribute substantial household income through selling of crops produced in wetlands. Farmer associations formed around wetland utilization obtain substantial benefits associated with social capital including loans/credit facilities and various forms of government support.

\section{REFERENCE}

Bwana EN. 1996. An assessment of the Adoption of Improved Foodgrain Storage structures in Mara Region. [Thesis]. Sokoine University of Agriculture, Morogoro, Tanzania.

Chambers R, Conway GR. 1992. Sustainable Rural Livelihoods: Practical Concepts for the 21st Century. IDS Discussion Paper No. 296. IDS, Brighton.

DFID [Department for International Development]. 1997. Eliminating World Poverty: A Challenge for the 21st Century. Department for International Development, London.

Dugan PJ. 1990. Wetland Conservation: A Review of Current Issue and Action Report. IUCN Publications, Glady, Switzerland.

Economics for the Environment Consultancy. 2005. The Economic, Social and Ecological Value of Ecosystem Services: A Literature Review. Food and Rural Affairs, Tanzania.

Ishengoma GC. 1998. The Role of Women in Household Food Security in Morogoro Rural and Kilosa Districts. [Dissertation]. Sokoine University of Agriculture, Morogoro, Tanzania.

IWMI. 2010. Using Wetlands Sustainably, Water Issue Brief. International Water Management Institute, Colombo, Sri Lanka.

Kajembe GC, Luoga EJ. 1996. Socio-economic Aspect of Tree Farming in Njombe District, Consultancy Report to the Natural Resources Conservation and Land Use Management Project. Sokoine University of Agriculture, Morogoro.

Kajembe GC, Wiersum KF. 1998. Bridging the gap between indigenous initiative and externally sponsored forestry interventions. Faculty of Forestry Record 67: 95-105.

Kashaigili JJ. 2006. Land Covers Dynamics and Hydrological Functioning of Wetlands in the Usangu Plains in Tanzania. [Dissertation]. Sokoine University of Agriculture, Morogoro, Tanzania.
Lorri WSM, Kavishe FP. 1990. Household food security and relation to nutrition. Proceedings National Workshop on Food security in Dar es Salaam. Tanzania.11-13 June.

Magembe L. 2007. Transformation of Valley-bottom Cultivation and Its Effects on Tanzanian Wetlands: A case Study of Ndembera Wetland Area in Iringa Region. [Thesis]. University of Florida, USA.

Malcolm DW. 1953. Sukuma Land: African People and Their Country. A Study of Land in Tanzania. OUP, London.

Maltby E. 1986. Water Logged Wealth, Why Waste the World's Wet Places? International Institute for Environment and Development, London.

Maro RS. 1995. Insitu Conservation of Natural Vegetations for Sustainable Production of Agro-pastoral System. A Case Study of Shinyanga, Tanzania. [Thesis]. Agricultural University of Norway, Helsinki.

MNRT. 2003. Sustainable Wetlands Management. Environment Support Programme (ESP), Tanzania.

MNRT. 2004. The Development and Implementation of an Integrated Management Plan of Kilombero Valley Flood Plain-Ramsar Site Identification Report, Dar es Salaam, Tanzania.

Morse S, McNamara N, Acholo M. 2009. Sustainable livelihood approach: a critical analysis of theory and practice. Geogr Paper 189: 3-4.

Mtenga KJ. 1999. Smallholder Seed Production in Tanzania: Potentials and Limitations. [Thesis]. Sokoine University of Agriculture, Morogoro, Tanzania.

Munishi PKT, Kilungu H. 2004. The contribution of wetlands to household income and food security: A case study of "Nyumba ya Mungu" wetland system in northern Tanzania Paper Presented at the Meeting of the National Wetlands Working Group (NWWG) 30 July 2004, Dar es Salaam.

Nagabhatla N, Finlayson CM, Selamuttu S.S, Zomer R and Diphoorn L. 2006. Wetland Dynamics-Links with spatial, ecological, livelihoods and gender-related issues in the western coastal belt of Sri Lanka: Proceedings of the Ninth Biennial Conference on Ecological Sustainability and Human Well-Being. New Delhi, India, 15-18 December 2006.

NBS. 2002. Households' survey. Colour Print Tanzania Ltd. National Bureau of Statistics Tanzania, Dar es Salaam, Tanzania.

Ramsar Convention Bureau. 2002. Ramsar COP8 DOC. 15: Cultural aspects of wetland. $8^{\text {th }}$ Meeting of the Conference of the Contracting Parties to the Convention on Wetlands (Ramsar, Iran, 1971). Valencia, Spain, 18-26 November 2002.

Sarris A, Savastano S, Christiansen, L. 2006. The role of Agriculture in reducing poverty in Tanzania: A household perspective from Rural Kilimanjaro and Ruvuma. FAO, Commodity and Trade Policy, Rome.

Scoones I. 1998. Sustainable Rural Livelihoods: A Framework for Analysis, Working Paper 72. Institute for Development Studies, Brighton, UK.

Shinyanga Municipal Profile. 2014. Shinyanga Municipal Profile Vol 2. Government printer, Shinyanga, Tanzania.

Turyahabwe N, Kakuru W, Tweheyo M, Tumusiime D. 2013. Contribution of wetland resources to household food security in Uganda. Agric Food Secur 2 (1): 1-12. DOI: 10.1186/2048-7010-2-5.

URT. 2007. Shinyanga Regional Socio-economic Profile. National Bureau of Statistics (NBS) and Shinyanga Regional Commissioners Office, Tanzania.

URT. 2013. World Bank Capacity Building Shinyanga Municipal Council. Shinyanga, Tanzania.

Yanda PZ, Majule EA, Mwakaje AG. 2005. Wetland utilization, poverty alleviation and environmental conservation in semi-arid areas of Tanzania; The Case of Singida Region. In: Bruce AL, Mahoo HF (eds) Proceedings of the East Africa Integrated River Basin Management Conference at SUA 2005. Sokoine University of Agriculture, Morogoro, Tanzania, 7-9 March 2005. 